\title{
Sustainable Electricity Generation Technologies in South Africa: Initiatives, Challenges and Policy Implications
}

\author{
Josephine K. Musango (Corresponding author)
}

Gauteng City-Region Observatory, a partnership between the University of Johannesburg, the University of the Witwatersrand, Johannesburg and the Gauteng Provincial Government

Private Bag 3, Wits 2050, South Africa

Tel: 27-11-717-7295 E-mail: josephine.musango@gcro.ac.za

Bamikole Amigun

Renewable Energy Group, National Biotechnology Development Agency a parastatal under the Federal Ministry of Science and Technology, Abuja, Nigeria

E-mail: koleamigun@nabda.gov.ng

Alan C. Brent

Centre for Renewable and Sustainable Energy Studies, School of Public Leadership

Stellenbosch University, South Africa

E-mail: acb@sun.ac.za

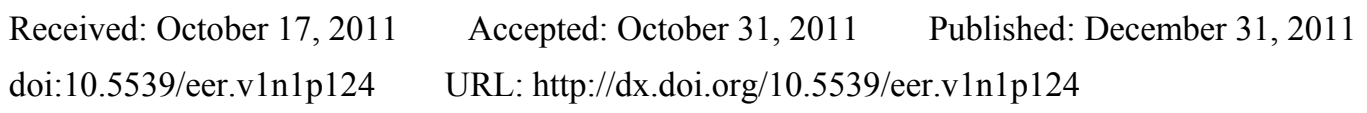

\begin{abstract}
Energy in the form of electricity is of key importance for economic development. South Africa has historically relied primarily on coal for electricity generation, making the electricity sector one of the dominant greenhouse gas emitters. Renewable energy and technologies have the potential to provide solutions such as greenhouse gas emission reduction, diversification of the energy mix, and job creation through manufacturing and industry development. Although South Africa has one of the best resources for wind, solar and biomass, the current renewable energy utilization for electricity generation is less than $2 \%$ of the total electricity generated. The last decade has subsequently been devoted to create renewable energy policies, incentives and plans in order to provide an enabling environment for renewable energy development. However, the deployment of renewable energy projects has (still) been slow. This study therefore provides an overview of the current status of policy and incentives that impact renewable electricity generation, the current renewable electricity generation initiatives, and challenges related to its development in South Africa. The policy implications and recommendations to support future development of renewable electricity generation include: establishing a single coordinating agency or authority; creating public awareness; providing financial support guarantees; and capacity building and skills development.
\end{abstract}

Keywords: Renewable electricity, sustainable development, South Africa

\section{Introduction}

Energy plays a critical role in the development of any nation's economy. The main challenges facing the energy sector globally are ensuring that the growing demand is met while at the same time providing security of supply and reducing greenhouse gas emissions (Zahedi, 2010). South Africa is energy and carbon intensive in comparison to other African countries. The energy sector is the main contributor of greenhouse emission as the country relies heavily on fossil fuels (Blignaut, 2005). In 2007, 84\% of the total primary energy share was from fossil fuels, of which $72 \%$ was from coal and $12.40 \%$ from oil (see Figure 1). The renewable energy contribution, which is only about $11 \%$ (Figure 1), is mainly fuel wood that meets the daily needs of more than one third of the South African population, particularly in the rural areas. 
The electricity sector in South Africa contributes to over $60 \%$ of the greenhouse gas emissions in the energy sector (Blignaut et al., 2005). The electricity generation by fuel type (Figure 2) shows the historical reliance on coal for electricity generation. The share of coal in electricity generation is more than $90 \%$ of the total electricity generated in South Africa (Republic of South Africa, 2009) while renewable electricity generation contributes around 2\% (United Nation Statistics Division, 2009). The renewable energy contribution has mainly been confined to non-grid electricity generation (Winkler, 2005).

The electricity demand in South Africa comes from five sectors. These are: industry, transport, agriculture, commerce and residential. Of these, industry has been the largest consumer of electricity (Department of Energy, 2009). In 2006, this sector accounted for $60 \%$ of the total energy demand (Table). Over the years, the total electricity demand has been increasing (Figure 3) and as a result, the electricity reserve margin has been declining. As an illustration, the reserve margin declined from $25 \%$ in 2002 to $20 \%$ in 2004 and afterwards to $16 \%$ in 2006 (Odhiambo, 2009). The declining electricity reserve margin intensified in 2008 and the country experienced its worst black-outs with substantial economic losses.

In order to improve electricity security and avoid further black-outs, there was a need to manage demand and supply through, respectively, demand side management strategies and electricity capacity expansion. As a last resort, the South Africa's national electricity utility, Eskom, intervened by embarking on load-shedding in order to better align the electricity generation with demand and at the same time maintain a reasonable electricity reserve margin (Odhiambo, 2009). This was followed by capacity expansion by Eskom, which included: (i) returning to service previous mothballed plants; and (ii) the start of construction of two coal-fired power plants (Medupi and Kusile) and a pumped storage scheme (Ingula) (Edkins et al., 2010). The installed capacity for these plants ${ }^{1}$ will be $4788 \mathrm{MW}$ (for Medupi), $4800 \mathrm{MW}$ (for Kusile) and 1.2 GW (for Ingula).

While Eskom's response was necessary to ensure short-term electricity security, the South African government's long-term energy policy goals is the establishment of conditions of security, stability and environmental protection. With such competing goals, the support for sustainable electricity generation becomes indispensible. Renewable energy offers an opportunity to reduce carbon emissions, enhance energy diversity, promote economic development, and aid the transition towards a sustainable path.

The potential for renewable electricity generation in South Africa is high (Pegels, 2010) and this is supported by various studies (Howells, 1999; DME 2002a; 2002b cited in Winkler, 2005). However, unlike a number of other countries that are embracing renewable electricity generation and paving the way for new initiatives, Africa, and particularly South Africa, still lags behind in such initiatives (South Africa National Energy Association, 2010). While electricity generation from coal is considered as the short-term best option, in the medium- to long-term, there is need to diversify the electricity generation mix due to environmental issues related to coal generated electricity. The recently approved Integrated Resource Plan (IRP2010) provides support for such a development and it indicates that $42 \%$ of the new built capacity will be from renewable sources by 2030 (Department of Energy, 2011). The South African Department of Energy also set out the first phase of renewable energy bidding process of a total capacity of $3725 \mathrm{MW}$ (Creamer, 2011a).

Renewable electricity generation, however, faces a number of general challenges and barriers that limits its widespread deployment. These can be classified as: natural factors, economic and financial factors, institutional and regulatory barriers, infrastructure barriers, research and development, human resources barriers, infrastructure and social barriers (Painuly, 2001; Ghosh et al., 2001; Junfeng, 2002; Reddy, 2002; Fakir and Nicol, 2008; Mirza et al., 2009; Pegels, 2010; Edkins et al., 2010). Thus, in order to ensure sustainable renewable electricity generation, proper planning and efforts accounting for these challenges and problems that may affect such development is required. While South Africa is pursuing programmes of generating electricity from coal, the renewable energy sources provide alternative options, which also need to be pursued. Thus, this paper provides the current policy and incentives that affect renewable electricity generation, as well as the status of developments, in South Africa. The general barriers to the deployment of these electricity generation technologies, with reference to South Africa context and the policy implications, are then discussed.

\section{Policy Documents and Incentives that Affect Renewable Electricity Generation in South Africa}

\subsection{White Paper on renewable energy, 2003}

This is the founding document aimed at promoting renewable energy development in South Africa. The White Paper set a target of $10000 \mathrm{GWh}$ of renewable energy contribution to final energy consumption by 2013, to be produced from biomass, wind, solar and small-scale hydro (Department of Minerals and Energy, 2003). Almost a decade down the line, it is not yet documented how much of this target has been achieved thus far, although it is believed to be negligible. 


\subsection{Electricity regulation Act as Amended, 2006}

One of the main objectives of this Act is to promote the use of diverse energy sources. Within the Act, the Minister of Energy, in consultation with the National Energy Regulator South Africa (NERSA), may determine "the energy sources from which electricity should be generated, and the proportion of electricity that should be generated from such sources" (Republic of South Africa, 2006).

\subsection{Renewable energy feed-in tariff, $2009 \& 2011$}

The South African government identified available financing as one of the barriers to renewable energy development. As a result, the renewable energy feed-in tariff (REFIT) was announced in 2009. In 2011, NERSA published a proposed review of the 2009 tariffs (Table 2), although these were never implemented. In the same year, REFIT was no longer favoured by the government as it was found unconstitutional. The first phase of the renewable energy procurement process thus abandoned the REFIT in favour of competitive bidding, which popularised the term REBID ${ }^{2}$.

\subsection{Electricity regulations on new generation capacity, 2009}

The electricity regulations apply to all technologies, including renewable energy. Their main aim is to regulate the entry by a buyer and an independent power producer (IPP) into a power purchasing agreement (Department of Energy, 2009).

\subsection{Integrated Resource Plan (IRP), 2010}

The primary objective of the IRP is to determine the long-term electricity demand and indicate how this demand should be met in terms of the generation type and timing. Currently, the IRP 2010 allocates 17800 MW (42\%) of renewable based electricity generation by 2030 (Department of Energy, 2009). The IRP is expected to be reviewed regularly (every two years) as new information and data becomes available.

\subsection{New Growth Path, 2010}

The new growth path plan sets an ambitious goal of creating 5 million jobs by 2020 . The new growth path does not provide what model was used to achieve this target and how it would be achieved. It, however, assumes that this target will mainly be achieved from the private sector. Among the sectors that are expected to contribute to this job creation is the 'green' industry sectors - of which renewable energy forms part.

\subsection{Industrial Policy Action Plan (IPAP), 2011}

South Africa has developed and implemented a number of IPAP versions. In the 2011 version, the IPAP highlights some of the plans in the renewable energy sector, which are mainly aimed at developing competitive local manufacturing for renewable energy technologies such as solar (concentrating solar thermal and photovoltaic) and wind (Department of Trade and Industry, 2011).

\subsection{Independent System and Market Operator (ISMO) Bill, in progress}

This bill aims at establishing the ISMO as a company responsible for the planning of the electricity supply by electricity generators through the national transmission system, electricity dispatch and aggregation in respect of the sale of electricity (Department of Energy, 2011). The ISMO is intended to act as the buyer of electricity from the generators in South Africa, and also a seller to its customers, and should do so in a manner that minimise the overall cost of electricity to customers (Department of Energy, 2011).

\subsection{New buildings and home upgrade regulations, in progress}

Based on the IPAP 2011, the South Africa Department of Trade and Industry (DTI) intends to amend the national building regulations in order to make it compulsory to install solar water heaters in all new buildings and upgrades to homes (Gedye and Donnelly, 2011).

\subsection{Climate change policy white paper, in progress}

The policy is still under development and it is aimed at assisting in the scale-up of the clean-, low-carbon-technology market in South Africa. It was expected to be tabled to the parliament in June 2011 but this has not yet occurred (van der Merwe, 2011).

\section{Status of Renewable Electricity Generation Development in South Africa}

The renewable energy resources that have the potential for electricity generation development in South Africa include: wind, solar, biomass and hydro. Their current status and their potential for development are discussed in the following sub-sections. 


\subsection{Wind energy}

Wind energy is one of the thriving renewables in the global arena and its use has been on the increase (Global Wind Energy Council, 2009). In South Africa, there is the potential for electricity generation from wind energy along the coastal areas (Asamoah, 2003; Sebitosi and Pillay, 2008), particularly in the Western Cape Province and parts of the Eastern Cape Province, and the Northern Cape Provinces (Hagemann, 2008). According to Szewczuk and Prinsloo (2010), several studies provide estimates of the wind energy potential in South Africa and range from a low of $500 \mathrm{MW}$ to a high of $56000 \mathrm{MW}$.

\subsubsection{Status of wind electricity generation}

The present situation into the applicability of wind energy development in South Africa is largely driven by the private sector (ESASTAP, 2005). Darling wind farm is the first commercial initiative for wind electricity production, which was launched in 2008 (Davenport, 2008). This was developed as a national demonstration project, located $70 \mathrm{~km}$ north of Cape Town and has an installed capacity of 5.2 MW. The phase II of the Darling wind farm will entail installing six 1.3 MW wind turbines that will result in a total installed capacity of $13 \mathrm{MW}$.

Another wind initiative is Klipheuwel, which is a research and demonstration project funded by Eskom at a cost of R42 million. The project is aimed at demonstrating the characteristics of three wind turbines, namely: the Danish Vestas V47, which has an installed capacity of $66 \mathrm{~kW}$, and V66 with a $1.75 \mathrm{MW}$ installed capacity and the French Jeumont J48 with a capacity of $750 \mathrm{~kW}$ (Smit, 2008). Eskom started generating the electricity from these three wind turbines with the aim of investigating the viability of large scale wind energy for electricity generation in South Africa (van der Merwe, 2009a). Eskom's future wind development is an additional 100 MW installed capacity at the Koekenaap wind farm.

There are other developers that have initiated some wind energy projects but have not been able to reach the implementation stages. For instance, according to the IRP, the South African government committed $700 \mathrm{MW}$ to be generated from wind energy by 2013 (South Africa Alternative Energy Association, 2010). In the first phase of the renewable energy bidding process, this capacity was upped and $1850 \mathrm{MW}$ was allocated for onshore wind (Creamer, 2011a). However, the prevailing thought is that up to $5000 \mathrm{MW}$ of wind power could be developed within a five year period (Bond, 2011). The wind energy projects that are being developed would therefore need to compete for the off-take of their power. These decisions would likely be based on affordability, especially regarding grid connection, as well as the broad-based black economic empowerment shareholding of a project (Pieters, 2009). In the integrated resource plan, the long-term future wind energy development is to reach 8400 MW by 2030 (Department of Energy, 2011).

\subsection{Solar energy}

Solar power is a renewable energy that taps the sun's energy to produce electricity through a solar thermal system or by photovoltaic systems. In South Africa, there is an enormous potential for the development of solar energy since the country has $24 \%$ of the world's best winter sunshine area (Figure 4), as well as some of the best annual irradiation (Holm et al., 2008; Fluri, 2009).

The IRP also allocates a large portion of grid-connected electricity generation from solar. The planned allocations for solar technologies are $8400 \mathrm{MW}$ by 2030 for large-scale photovoltaic (PV) and $1000 \mathrm{MW}$ for concentrating solar power (CSP) by 2030 (Department of Energy, 2011). Thus, photovoltaic (PV) is expected to play a key role at a utility scale in South Africa. The first phase of the solar energy development as per the renewable energy bidding process is $200 \mathrm{MW}$ for concentrated solar thermal and $1450 \mathrm{MW}$ for photovoltaic (Creamer, 2011a).

\subsubsection{Status of electricity generation from solar}

Currently there is no existing medium- to large-scale electricity generation from CSP and PV in South Africa. There is only a $24 \mathrm{~kW}$ dish Stirling plant that was built as a demonstration at the Development Bank Southern Offices in Midrand, Johannesburg in order to coincide with the World Summit on Sustainable Development (United Nations Industrial Development Organizations, 2003). Photovoltaic technologies on the other hand are not only applicable at utility scale, but also have a potential at small scale such as household and industry systems. Small-scale PV has been used for electricity generation for telecommunications, electronic media and lighting in remote areas that are far from the grid (Edkins, 2010). The estimated installed solar PV capacity in South Africa is around 12 MW (van der Merwe, 2009b).

While there are no utility-scale solar technology plants, there are, however, a number of feasibility studies that are underway to develop plants of such a scale. For instance, one of the programmes to tap solar energy is the 
Solar Park in the Northern Cape Province. The proposed capacity of the solar park is 5 GW by 2020, in which the first phase is planned to develop $1 \mathrm{GW}$ by 2016 (Department of Energy, 2010).

\subsection{Hydro power}

Hydro power schemes convert the potential energy of the water flowing with a certain fall into usable energy, and can be categorised in different scales. This ranges from pico-hydro with up to $20 \mathrm{~kW}$ power output to macro-hydro that is greater than $10 \mathrm{MW}$ power output (Table ).

\subsubsection{Status of electricity generation from hydropower}

South Africa is a water scarce country (Blignaut and van Heerden, 2009) with an average rainfall of $500 \mathrm{~mm}$ per annum. The potential to develop hydropower is thus limited to pico-, micro-, mini- and small-hydro. These are mainly situated in dams, pipelines and canals. The current installed capacity for these categories is $38 \mathrm{MW}$ and the estimated potential is $247 \mathrm{MW}$ (see Table).

The opportunities for developing pico-, micro-, mini-, and small-hydro in South Africa, include, among others (Barta, 2011): (i) the upgrade of the existing plants that are owned by the Department of Water Affairs and municipalities - this has a potential to generate up to $70 \mathrm{GWh}$ per annum; (ii) setting up hydro power stations on existing or new dams - currently, there are about 300 dams that are suitable for this development and have a potential to generate up to $500 \mathrm{GWh}$ per annum; (iii) inter-basin water transfers, which has a potential to generate up to $300 \mathrm{GWh}$ per annum; (iv) making use of the municipal or water distribution systems and has a potential to generate between 250 and $500 \mathrm{GWh}$ per annum; and (v) if storage is regulated, developing hydro in "Greenfields". The first phase of renewable energy bidding process only allocated $75 \mathrm{MW}$ for small-scale hydro power (Creamer, 2011a).

South Africa can also benefit from macro-hydro by importing from its neighbouring countries that have a huge hydropower development potential, from pumped storage, and from dams/transfers (see Table ). Currently, South Africa has an installed capacity of $1580 \mathrm{MW}$ and $662 \mathrm{MW}$ from pumped storage and dams/transfers respectively.

The potential for South Africa to utilize imported hydropower is large and the current imports amount to 1450 MW (Table ). The largest import potential is mainly from Democratic Republic of Congo (DRC), Mozambique and Zambia, with available development potentials of $60000 \mathrm{MW}, 12500 \mathrm{MW}$ and $6000 \mathrm{MW}$ respectively (Table).

\subsection{Biomass}

Biomass is a renewable energy resource derived from wastes of various human and natural activities. The energy from biomass can be categorized into two distinct sources, namely: wood and waste. The main contributors to woody biomass resources include: timber industry, agricultural crops and raw materials from forestry. Waste is derived from municipal solid waste and manufacturing waste.

Currently, most of the renewable energy in South Africa is derived from biomass. According to Lynd et al (2003) South Africa produces around 18 million tonnes per annum of agricultural and forestry residues (Table 6). In addition, they indicated that the invasive alien species would produce more than 8 million tonnes per annum. Marrison and Larson (1996) also projected that South Africa has a potential to provide an additional 67 million tonnes of energy crops on $10 \%$ available land. This available land excludes the forest land, crop land and wilderness (Marrison and Larson, 1996). As observed in Table 6, there is potential to use biomass from agricultural wastes and wood residues for energy production.

\subsubsection{Status of electricity generation from biomass}

There are a number of technological options available to make use of a wide variety of biomass types to generate energy. Conversion technologies may release the energy directly, in the form of heat or electricity, or may convert it to another form, such as liquid biofuel or combustible biogas. In South Africa, the estimated electricity generation from biomass amounts to about 20 MW (CaBEERE, 2004 cited in Holms et al., 2008). This might be slightly higher given the current interest in the landfill waste to electricity generation in South Africa. In 2010, a 7.5 MW landfill gas to energy was inaugurated in eThekwini Municipality (Durban). This is the first plant of this kind in South Africa. Though the plant is not connected to the national grid, the electricity generated is utilized by the municipality, hence decreasing its demand for electricity from the national grid. In addition, the power utility in South Africa has been looking into the potential of using the biomass from municipal waste and wood-based biomass for firing or co-firing the existing coal plants (Thomaz, 2009; de Bruyn, 2010). The amount 
of electricity generation that was allocated in the current renewable energy bidding process is $12.5 \mathrm{MW}$ for both biomass and biogas, and $25 \mathrm{MW}$ for landfill gas capacity (Creamer, 2011)

\section{Challenges for Sustainable Electricity Generation Technology Development in South Africa}

The challenges and barriers that affect the deployment of renewable electricity generation need to be accounted for in the short-, medium and long-terms in order to ensure their sustainable development. A discussion of these barriers with specific reference to South African condition is provided in the sub-sections.

\subsection{Natural barriers}

The natural barriers include the resource availability to develop the renewable electricity generation technologies. South Africa, for instance, is water scarce and hence it has a limitation on the extent to which hydro power can be developed. Only small-hydro plants can be developed within South Africa. In a similar manner, wind resource in South Africa is mainly concentrated along the coastal areas and hence it cannot be developed in all the provinces of South Africa. On the other hand, all the provinces of South Africa have a potential to develop solar power technologies (Fluri, 2010; Pegels, 2010), although the availability of water for the power block remains problematic in terms of providing conventional wet cooling.

\subsection{Economic and financial barriers}

The economic barriers to renewable energy development in South Africa include risk and cost of investment (Pegels, 2010). The low predictability and uncertainty of the renewable energy capital return on investment often limits the financial support and mechanisms in the form of grants and loans for the renewable electricity technologies. This is because these investments are not very attractive particularly with the high interest rates. This lack of financial support for the potential investors is thus a major barrier to the medium- to large-scale deployment of the renewable electricity generation in South Africa.

On the other hand, the cost of developing the renewable electricity generation technologies, the use and maintenance thereof, is still high compared to the conventional technologies such as coal or natural gas. South Africa's long history of supplying cheap electricity due to a dramatic over-capacity expansion programme in the 1970s has made renewable energy generation less competitive (Edkins et al., 2010). In order to overcome this challenge, South Africa had published renewable energy feed-in-tariff (REFIT) scheme in 2009 and a proposed review for these tariffs in 2011 (Table 2). However, the REFIT was abandoned in favour of competitive bidding (Creamer, 2011b). This created mixed reactions where some new risks were being identified (Creamer, 2011c), while in other cases the bidding process was embraced (Creamer, 2011d). Thus, the general perception of the bidding process and the uncertainty it has created to the renewable energy developers is unclear.

\subsection{Institutional and regulatory barriers}

Electricity generation at medium- to large-scale requires a number of legal and regulatory prerequisites by different government departments/stakeholders and authorities. The consequence is that there are too many agencies that are involved and it takes a long time to approve and issue licences such as the environmental impact assessment licences and generation licences (Edkins et al., 2010). The regulatory requirements by the different government departments are also uncoordinated. This implies that the electricity generation developers may be required to submit similar information and documents to the different departments or agencies. All these institutional and regulatory barriers have been cited by the developers as one of the largest hurdles in deploying renewable energy (Fakir and Nicol, 2008), and are summarized in Table 7.

\subsection{Social barriers}

Social barriers of renewable electricity development include the possibility of rejection of such projects by the local authorities and communities (Amigun et al., 2011). In many cases, there is always a divergence in the attitudes of the renewable energy technologies at national, regional and local levels. In order to ensure successful implementation of renewable electricity generation, there is a need for public awareness concerning the renewable energy projects. This is because renewable electricity projects require resources such as land (private or communal), which has other competing uses. In cases where the land is communally owned, there is a definite need to gain community acceptance. As observed by Amigun et al. (2011), land is considered as an inheritance and the successful implementation of renewable energy projects requires the government and project developers to work closely with the communities in the areas / regions earmarked for these developments.

\subsection{Human resource barriers}

Trained manpower capable of developing and manufacturing renewable energy technologies is a prerequisite for its successful deployment. Most renewable energy technology development will not only require low-skilled 
manpower, but also highly skilled, technical manpower. The South African government has put much emphasis on job creation in the development of renewable energy. While the need for creating jobs is recognized, the manpower resources, as well as skills of management and use of technology and equipment, are still limited. It is thus necessary to clearly outline how the supply of skilled and technical manpower will be achieved. In addition, it is necessary to identify and understand the training needs in this new field within South African context.

\subsection{Infrastructure}

Developing new renewable resources requires large initial investments to build infrastructure. These investments increase the cost of providing renewable electricity, especially during early years. Examples include the following:

- Prospecting: developers are required to find publicly acceptable sites with good resources and with access to the transmission system. The development of the transformers and transmission lines to evacuate the renewable energy capacity requires long lead times. It also takes time to investigate the suitability of developing renewable energy in specific sites. For instance, the potential wind sites can require several years of monitoring to determine whether they are suitable.

- Permitting: permitting issues for conventional energy technologies are generally well understood, and the process and standards for new capacity are well defined. In contrast, renewables often involve new types of issues and ecosystem impacts. And standards and regulations are still in the process of development.

\section{Policy Implications}

The Intergovernmental Panel for Climate Change (IPCC) report on technology transfer clearly highlights the role of governments in facilitating technology transfer (Intergovernmental Panel for Climate Change, 2000), which is also applicable for renewable electricity generation technologies. The roles that are identified include the removal of barriers to technology transfer; capacity building both human and for institutions; providing an enabling environment that is suitable for the investment, provision of infrastructure for research and development; and information transfer and provision of support mechanism for renewable energy deployment.

From a policy perspective, the promotion of the renewable electricity generation technologies requires the identification of the barriers to such development and designing policy actions that facilitate the move towards implementation and operationalization of the renewable electricity deployment in order to overcome the barriers discussed above. Some measures suggested here include:

i. The standardization of regulatory requirements from the different departments and authorities could minimize the regulatory requirement challenges. In addition, the establishment of a single authority or agency that may coordinate all the regulatory requirements may reduce the time delays and provide coordination between the different departments involved.

ii. In order to reduce the public resistance towards the development of renewable electricity generation technologies, there is a need to keep the public informed on the economic, social and environmental impacts of such developments in order for them to make informed choices. Public participation and engagement, specifically with those who might be impacted by renewable electricity development, may help in minimizing the delays in developing these projects.

iii. There is a need to provide financial mechanism that supports renewable electricity generation technologies in South Africa. Currently, the renewable energy feed-in tariffs were abandoned in favour of competitive bidding (currently termed as REBID). The window phase between the revision of the 2009 tariffs and the adoption of REBID created uncertainty of the uptake of renewables. While REBID is being embraced by some developers, there is still the need to be able to provide support mechanisms and guarantees that will enable the investors and developers to obtain financial support from the banks. This is in particular, for the small-scale developers that will mostly be local investors.

iv. Capacity building, skills development and technology transfer requires government support as this will also be needed, not only for the development of the generation plants, but also for the manufacturing industries to provide the necessary inputs. The Industrial Policy Action Plan (IPAP) does provide some of the local content for the various parts of the renewable energy technologies. To successfully achieve this, there is an urgent need for technology transfer from abroad in order to provide technical assistant programmes that are aimed at increasing the understanding of the renewable electricity generation technologies for the research institutions regulators, electricity utility and independent power producers. In doing so, this may play a key role in economic growth and job creation in the country. 


\section{Conclusion}

The potential for developing renewable electricity generation in South Africa, particularly wind, solar, biomass and small-scale hydro, is recognized. The current policy in South Africa, in particular the Integrated Resource Plan (IRP), provides a platform for the development of renewable electricity generation. In addition, the announcement and start of renewable energy bidding process sets in motion the large-scale implementation of renewable electricity generation. While these form initial strides towards the actualisation and bringing large-scale renewable electricity into the grid, there still exist a number of challenges that need to be addressed. Policy actions and strategies need to be designed in such a way that they can facilitate the implementation and operationalization of renewable electricity technologies. Some policy recommendations that have been highlighted in this study include: establishment of single coordinating agency or authority; public awareness; financial support guarantees particularly for local small-scale investors; and capacity building and skills development.

\section{References}

Amigun, B., Musango, J. K., \& Brent, A. C. (2011). Community perspectives on the introduction of biodiesel production in the Eastern Cape Province of South Africa: a questionnaire survey results. Energy, 362 (5), 2502-2508. http://dx.doi.org/10.1016/j.energy.2011.01.042

Asamoah, J. (2003). Greening electricity generation in South Africa through wind energy. In J. Gale, \& Y. Kaya (Eds). Greenhouse Gas Control Technologies - 6th International Conference (pp. 1349-1352). Pergamon, Oxford.

Barta, B. (2011). A low carbon future co-ordinated energy strategy suggestion. [Online] Available: http://www.omegainvest.co.za/LowCarbon-Programme.html (April 19, 2011).

Blignaut, J. N., Mabugu, R. M., \& Chitiga-Mabugu, M. R. (2005). Constructing a greenhouse gas emissions inventory using energy balances: the case of South Africa. Journal of energy in Southern Africa, 16(3), 105-116.

Blignaut, J., \& van Heerden, J. (2009). The impact of water scarcity on economic development initiatives. Water SA (Online), 35, 415-410.

Bond, L. (2011). Blowing in the wind - the who's who of the wind sector. Alternative Energy, 4(1), 22-25.

Creamer, T. (2011a). Renewable project developers pore over tender documents. [Online] Available: http://www.engineeringnews.co.za/article/renewables-project-developers-pore-over-tender-documents-2011-0804 (August 5, 2011).

Creamer, T. (2011b). Much at stake for developers, government as renewables bid process moves ahead. [Online] Available:http://www.engineeringnews.co.za/article/much-at-stake-for-developers-government-as-renewables-bi d-process-moves-ahead-2011-08-19 (August 20, 2011).

Creamer, T. (2011c). Wind developers see progress and new risks as they work through bid documents. [Online] Available:http://www.engineeringnews.co.za/article/wind-developers-see-progress-and-new-risks-as-they-work-t hrough-bid-documents-2011-08-24 (September 3, 2011).

Creamer. T. (2011d). New Energy. [Online] Available: http://www.engineeringnews.co.za/article/new-energy2011-09-23 (September 24, 2011).

Davenport, J. (2008). SA launches first commercial wind in $\mathrm{W}$ Cape. [Online] Available: http://www.engineeringnews.co.za/article/sa-launches-first-commercial-wind-farm-in-w-cape-2008-05-23 (September 28, 2010).

De Bruyn, C. (2010). Eskom wants to use wood-based biomass fuels to fire stations. [Online] Available: $\mathrm{http}: / / \mathrm{www}$.engineeringnews.co.za/article/eskom-wants-to-use-wood-based-biomass-fuels-to-fire-power-stations -2010-05-26 (December 7, 2010).

Department of Energy (2009). Electricity regulations on new generation capacity. [Online] Available: http://www.nersa.org.za/Admin/Document/Editor/file/Electricity/Legislation/Regulations/Electricity\%20Regulat ions\%200n\%20new\%20generation\%20capacity.pdf (November 15, 2011).

Department of Energy. (2009). Digest of South African energy statistics 2009. [Online] Available: http://www.energy.gov.za/files/media/explained/2009\%20Digest\%20PDF\%20version.pdf (October 3, 2011).

Department of Energy. (2010). Real sun, real power: the solar park investors' conference. [Online] Available: http://www.energy.gov.za/Solar\%20Park/2010/Solar\%20Park\%20Investors\%20Conference\%20Report\%2028-2

9\%20October\%202010.pdf (October 3, 2011). 
Department of Energy. (2011). Independent System Market Operator. [Online] Available: http://www.energy.gov.za/files/policies/1-34289\%2013-5\%20ISMO\%20Establishment\%20Bill\%20for\%20Publi c\%20Comments.pdf (October 3, 2011).

Department of Energy. (2011). Integrated Resource Plan 2010: Electricity. [Online] Available: http://www.doe-irp.co.za/ (April 17, 2011).

Department of Minerals and Energy. (2003). White Paper on renewable energy. [Online] Available: http://unfccc.int/files/meetings/seminar/application/pdf/sem_sup1_south_africa.pdf (September 28, 2011).

Department of Minerals and Energy. (2006). Digest of South African energy statistics. [Online] Available: www.dme.gov.za/pdfs/energy/planning/2006\%20Digest.pdf (October 18, 2010)

Department of Minerals Energy. (2004). Economic and Financial Calculations and Modelling for the Renewable Energy Strategy Formulation, CABEERE Report No. 2.3.4 - 19. Pretoria: Department of Minerals and Energy.

Department of Trade and Industry. (2011). Industrial Policy Action Plan 2011/2012 - 2013/2014. [Online] Available: http://www.info.gov.za/view/DownloadFileAction?id=144975 (May 2, 2011).

Edkins, M., Marquard, A., \& Winkler, H. (2010). Assessing the effectiveness of national solar and wind energy policies in South Africa. [Online] Available: www.erc.uct.ac.za/.../10Edkinesetal-Solar_and_wind_policies.pdf (April 5, 2011).

Energy Information Administration. (2010). International energy statistics. [Online] Available: http://www.eia.doe.gov/electricity/ (September 25, 2010).

ESASTAP. (2005). South Africa renewable energy research and development initiatives. [Online] Available: http://www.esastap.org.za/esastap/pdfs/esastap_saenergy_nov2005.pdf (December 12, 2010).

Fluri, T. P. (2009). The potential of concentrating solar power in South Africa. Energy Policy, 37(12). 5075-5080. http://dx.doi.org/10.1016/j.enpol.2009.07.017

Gedye, L., \& Donnelly, L. (2011). Green energy go-ahead. [Online] Available: http://mg.co.za/article/2011-0408-green-energy-goahead (April 8, 2011).

Ghosh, D., Shukla, P. R., Garg, A., \& Ramana, P. V. (2001). Renewable energy technologies for Indian power sector. CSH Ocassional Paper No. 3. New Delhi, India: centre de Sciences Humaines.

Global Energy Network Institute. (2010). South Africa. [Online] Available: http://www.geni.org/globalenergy/li brary/energytrends/currentusage/renewable/wind/global-wind-resources/south-africa/index.shtml (January 26, 2011).

Global Wind Energy Council. (2009). Global wind report 2009. [Online] Available: http://www.gwec.net/fileadmin/documents/Publications/Global_Wind_2007_report/GWEC_Global_Wind_2009 _Report_LOWRES_15th.\%20Apr.Pdf (April 4, 2010).

Hagemann, K. (2008). Mesoscale Wind Atlas of South Africa. PhD Dissertation, University of Cape Town. Cape Town: University of Cape Town.

Holm, D., Banks, D., Schaeffler, J., Worthington, R., \& and Afane-Okese, Y. (2008). Renewable Energy Briefing Paper: Potential for Renewable Energy to contribute to National Electricity Emergency Response and Sustainable Development. Pretoria: Departement of Energy. [Online] Available: http://www.earthlife.org.za/wor dpress/wp-content/uploads/2008/12/rebriefingpaperfinal5aug08.pdf (April 18, 2011).

http://www.sanea.org.za/MediaCentre/SANEATalkingEnergy/2010/April/12.asp (January 3, 2011).

Intergovernmental Panel for Climate Change. (2000). Methodological and technological issues in technology transfer. [Online] Available: http://www.ipcc.ch/pdf/special-reports/spm/srtt-en.pdf (April 12, 2011).

Junfeng, L., Zhu, L., Runqing, H., Zhengmin, Z., Jingli, S., \& Yangnin, S. (2002). Policy analysis of the barriers to renewable energy development in the People's Republic of China. Energy for Sustainable Development, 1(3), 11-20. http://dx.doi.org/10.1016/S0973-0826(08)60321-X

Lynd, L. R., von Blottnitz, H., Tait, B., de Boer, J., Pretorius, I. S., Rumbold, K., \& van Zyl, W. H. (2003). Plant Biomass Conversion to Fuels and Commodity Chemicals in South Africa: A Third Chapter? South African Journal of Science, 99(11), 499-507.

Marrison, C. I., \& Larson, E. D. (1996). A preliminary analysis of the biomass energy production potential in Africa in 2025 considering projected land needs for food production. Biomass and Bioenergy, 10(5-6), 337-351. http://dx.doi.org/10.1016/0961-9534(95)00122-0 
Mirza, U. K, Ahmad, N., Harijan, K., Majeed, T. (2009). Identifying and addressing barriers to renewable energy development in Pakistan. Renewable and Sustainable Energy Reviews, 13(4), 927-931. http://dx.doi.org/10.1016/j.rser.2007.11.006

NERSA. (2011). NERSA Consultation Paper Review of Renewable Energy Feed - In Tariffs. [Online] Available: http://www.nersa.org.za (April 21, 2011).

Odhiambo, N. M. (2009). Electricity consumption and economic growth in South Africa: A trivariate causality test. Energy Economics, 31(5), 635-640. http://dx.doi.org/10.1016/j.eneco.2009.01.005

Painuly, J. P. (2001). Barriers to renewable energy penetration - a framework analysis. Renewable Energy, 24(1), 73-89. http://dx.doi.org/10.1016/S0960-1481(00)00186-5

Pegels, A. (2010). Renewable energy in South Africa: potentials, barriers and options for support. Energy Policy, 38(9), 4945-4954. http://dx.doi.org/10.1016/j.enpol.2010.03.077

Reddy, A. K. N. (2002). A generic Southern perspective on renewable energy. Energy for Sustainable Development, 1 (3), 74-83. http://dx.doi.org/10.1016/S0973-0826(08)60327-0

Republic of South Africa. (2006). The electricity regulation Act, 2006. [Online] Available: http://www.info.gov.za/view/DownloadFileAction?id=67855 (September 28, 2011).

Republic of South Africa. (2009). South Africa yearbook 2009/10. GCIS, Pretoria, South Africa pp. 182-201.

Sebitosi, A. B. \& Pillay, P. (2008). Grappling with a half-hearted policy: the case of renewable energy and the environment in South Africa. Energy policy, 36 (7), 2513-2516. http://dx.doi.org/10.1016/j.enpol.2008.03.011

Smit, I. (2008). Eskom's experience in wind energy. [Online] Available: http://www.25degrees.net/index.php? option $=$ com_zine\&view $=$ article\&id=248:eskoms-experience-in-wind-energy\&Itemid=123 (April 19, 2011).

South Africa Alternative Energy Association. (2010). Eskom to publish grid-connection road map by year-end. [Online] Available: http://saaea.blogspot.com/2010/11/eskom-to-publish-grid-connection-road.html (January 4, 2011).

South Africa national energy association. (2010). A new era for renewable energy.

STATS SA (2011). Electricity produced and consumed in power stations, purchased and sold outside South Africa and available for distribution in South Africa. [Online] Available: www.conference.csir.co.za (April 19, 2011). http://www.statssa.gov.za/ (November 15, 2011).

Szewczuk, S., \& Prinsloo, E. (2010). Wind Atlas for South Africa (WASA): Project overview and current status. Science real and relevant conference, 2010. [Online] Available: www.conference.csir.co.za (April 19, 2011).

Thomaz, C. (2009). Municipal solid waste energy study under way. [Online] Available: http://www.engineeringnews.co.za/article/municipal-solid-waste-energy-resource-feasibility-study-underway-20 09-05-15 (December 4, 2010).

United Nation Statistics Division. (2009). Environment statistics - Country snapshots. [Online] Available: http://unstats.un.org/unsd/environment/envpdf/Country_Snapshots_Sep\%202009/South\%20Africa.pdf (March 3, 2011).

United Nations Industrial Development Organizations. (2003). Clean development mechanism investors guide: South Africa. [Online] Available: http://www.unido.org/fileadmin/media/documents/pdf/Energy_Environment/ CDM_guide_SouthAfrica_pdf (September 6, 2011).

Van der Merwe, C. (2009a). 40-MW wind-power project planned for Tsitsikamma [Online] Available: http://m.engin eeringnews.co.za/article/40-mw-wind-power-project-planned-for-tsitsikamma-2009-11-30 (January 12, 2011).

Van der Merwe, C. (2009b). Renewable feed-in tariff could include large-scale PV projects, study shows. [Online] Available: http://www.engineeringnews.co.za/article/renewable-feed-in-tariff-could-include-large-scale -pv-projects-study-shows-2009-06-02 (October 20 2010).

Van der Merwe, C. (2011). SA needs strong, clear policy signals on climate change. [Online] Available: http://www.engineeringnews.co.za/article/strong-clear-policy-signals-on-climate-change-required-by-govt-201109-02 (October 03, 2011).

Winkler, H. (2005). Renewable energy policy in South Africa: policy options for renewable electricity. Energy Policy, 33 (1), 27-38. http://dx.doi.org/10.1016/S0301-4215(03)00195-2 
World Energy Outlook (2009). Access to electricity. [Online] Available: http://www.worldenergyoutlook.org/ electricity.asp (April 17, 2011).

Zahedi, A. (2010). Australian renewable energy prospects. Renewable and Sustainable Energy Reviews, 14 (8), 2208-2213. http://dx.doi.org/10.1016/j.rser.2010.03.026

\section{Notes}

Note 1. Refer www.eskom.co.za for more details

Note 2. This term is derived from the words renewable energy bidding (REBID)

Table 1. Main electricity consumers in 2006

\begin{tabular}{|l|l|l|}
\hline Sector & GWh & $\%$ \\
\hline Industry & 116631 & 60.0 \\
\hline Transport & 3480 & 1.8 \\
\hline Agriculture & 5841 & 3.0 \\
\hline Commerce & 28833 & 14.8 \\
\hline Residential & 39671 & 20.4 \\
\hline
\end{tabular}

Source: Department of Energy (2009)

Table 2. 2009 REFIT and 2011 Revised REFIT with projected CPI adjustments for years 2012-2013

\begin{tabular}{|l|l|l|l|l|}
\hline Technology & $\begin{array}{l}\text { REFIT 2009 } \\
\text { R/kWh }\end{array}$ & $\begin{array}{l}\text { REFIT 2011 } \\
\text { R/kWh }\end{array}$ & $\begin{array}{l}\text { REFIT 2012 } \\
\text { R/kWh }\end{array}$ & $\begin{array}{l}\text { REFIT 2013 } \\
\text { R/kWh }\end{array}$ \\
\hline Wind > 1MW & 1.25 & 0.938 & 0.945 & 0.952 \\
\hline Landfill > 1MW & 0.90 & 0.539 & 0.550 & 0.562 \\
\hline Small hydro > 1MW & 0.94 & 0.671 & 0.675 & 0.680 \\
\hline $\begin{array}{l}\text { CSP trough > 1MW with 6 hrs } \\
\text { storage }\end{array}$ & 2.10 & 1.836 & 1.845 & 1.854 \\
\hline $\begin{array}{l}\text { CSP trough > 1MW without } \\
\text { storage }\end{array}$ & 3.14 & 1.938 & 1.953 & 1.967 \\
\hline $\begin{array}{l}\text { CSP central receiver (lower) }> \\
1 \text { MW with TES 6hrs }\end{array}$ & 2.31 & 1.399 & 1.408 & 1.417 \\
\hline $\begin{array}{l}\text { Photovoltaic > 1MW ground } \\
\text { mounted }\end{array}$ & 3.94 & 2.311 & 2.325 & 2.338 \\
\hline $\begin{array}{l}\text { Biomass solid }>1 \mathrm{MW} \text { (direct } \\
\text { combustion) }\end{array}$ & 1.18 & 1.060 & 1.084 & 1.108 \\
\hline Biogas >1MW & 0.96 & 0.862 & 0.862 & 0.887 \\
\hline
\end{tabular}

Source: NERSA (2011) 
Table 3. Categories for hydropower generation

\begin{tabular}{|l|l|l|}
\hline Category & Power output & Typical generation time (\%) \\
\hline Pico & Up to $20 \mathrm{~kW}$ & $10-35$ \\
\hline Micro & 20 to $100 \mathrm{~kW}$ & $10-35$ \\
\hline Mini & $100 \mathrm{kw}$ to $1 \mathrm{MW}$ & $10-75$ \\
\hline Small & 1 to $10 \mathrm{MW}$ & $35-85$ \\
\hline Macro & $>10 \mathrm{MW}$ & $35-95$ \\
\hline
\end{tabular}

Source: Barta, 2011

Table 4. Hydropower potential in South Africa

\begin{tabular}{|l|l|l|l|}
\hline \multicolumn{2}{|l|}{ Category } & Installed capacity (MW) & Estimated potential (MW) \\
\hline Pico, micro, mini \& small & 38 & 247 \\
\hline \multirow{3}{*}{ Macro } & Imported hydro & 1450 & 36400 \\
\cline { 2 - 5 } & Pumped storage & 1580 & 10400 \\
\cline { 2 - 5 } & Dams/transfers & 662 & 6990 \\
\hline
\end{tabular}

Source: Barta, 2011

Table 5. Imports hydropower potential from SADC

\begin{tabular}{|l|l|l|}
\hline Country & $\begin{array}{l}\text { Hydro installed capacity } \\
(\mathrm{MW})\end{array}$ & $\begin{array}{l}\text { Available development potential } \\
(\mathrm{MW})\end{array}$ \\
\hline Angola & 291 & 1200 \\
\hline Botswana & Nil & - \\
\hline DRC & 2442 & 60000 \\
\hline Lesotho & 76 & 450 \\
\hline Malawi & 245 & 600 \\
\hline Mozambique & 2184 & 12500 \\
\hline Namibia & 240 & 120 \\
\hline Swaziland & 62 & 200 \\
\hline Tanzania & 396 & 3000 \\
\hline Zambia & 1670 & 6000 \\
\hline Zimbabwe & 666 & 1500 \\
\hline
\end{tabular}

Source: Barta, 2011 
Table 6 . Summary of biomass availability by type

\begin{tabular}{|c|c|c|c|}
\hline \multicolumn{2}{|c|}{ Biomass type } & Quantity (Mt/yr) & $\begin{array}{ll}\text { Energy } & \text { equivalent } \\
(\mathrm{PJ} / \mathrm{yr}) & \end{array}$ \\
\hline \multicolumn{4}{|c|}{ 1. Residuals } \\
\hline \multicolumn{4}{|c|}{ a. Agricultural } \\
\hline & Maize stover & 6.7 & 118 \\
\hline & Sugar cane bagasse & 3.3 & 58 \\
\hline & Wheat straw & 1.6 & 28 \\
\hline & Sunflower stalks & 0.6 & 11 \\
\hline & Sub-total & 12.3 & 214 \\
\hline \multicolumn{4}{|c|}{ b. Forestry } \\
\hline & Left in the forest & 4.0 & 69 \\
\hline & Sawmill residue & 0.9 & 16 \\
\hline & Paper and board mill sludge & 0.1 & 2 \\
\hline & Subtotal & 5.0 & 87 \\
\hline \multicolumn{4}{|c|}{ 2. Energy crops } \\
\hline & From 5\% available land & 34 & 584 \\
\hline & From $10 \%$ available land & 67 & 1170 \\
\hline & From $20 \%$ available land & 134 & 2330 \\
\hline \multicolumn{4}{|c|}{ Total annual basis } \\
\hline \multicolumn{2}{|r|}{ (assuming $10 \%$ available land) } & 84 & 1470 \\
\hline 3. & Invasive plant species & 8.7 & 151 \\
\hline
\end{tabular}

Source: Lynd et al. (2003)

Table 7. Institutional and regulatory barriers facing renewable energy developers

\begin{tabular}{|c|c|}
\hline Category & Barriers \\
\hline Institutional & $\begin{array}{l}\text { - Too many agencies involved in approvals } \\
\text { - Time to process approvals for licenses, environmental impact assessment } \\
\text { or negotiation of purchasing power agreement } \\
\text { - Identifying the right public sector finance partner } \\
\text { - Clean development mechanism process is expensive and long }\end{array}$ \\
\hline Regulatory / legal & $\begin{array}{l}\text { - Environmental impact assessment laws, planning legislation, the Public } \\
\text { Financer Management Act (PFMA), Municipal Finance Management Act } \\
\text { (MFMA) } \\
\text { - Rights to access property or resource }\end{array}$ \\
\hline
\end{tabular}

Source: Adapted from Fakir and Nicol (2008) 


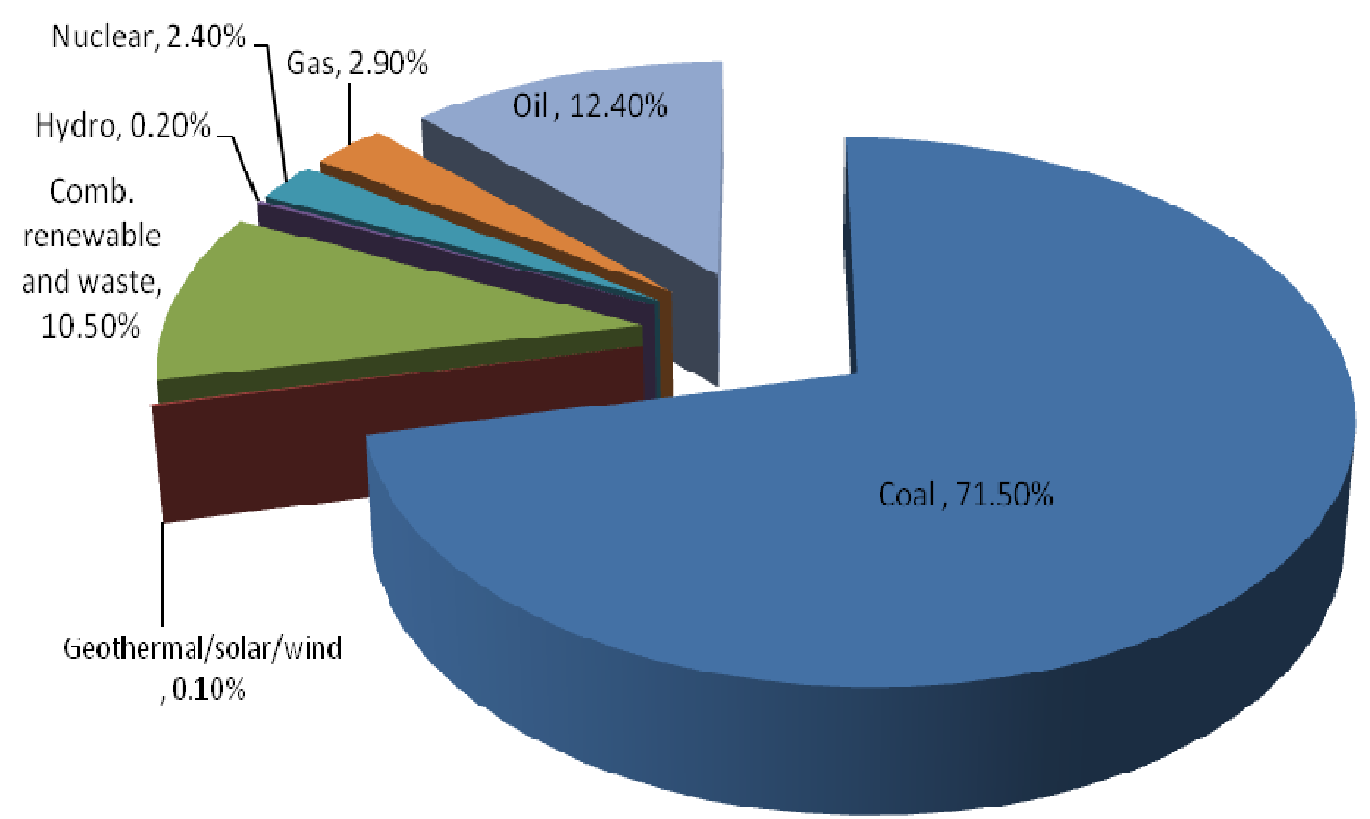

Figure 1. Total primary energy share in South Africa (Energy Information Administration, 2010)

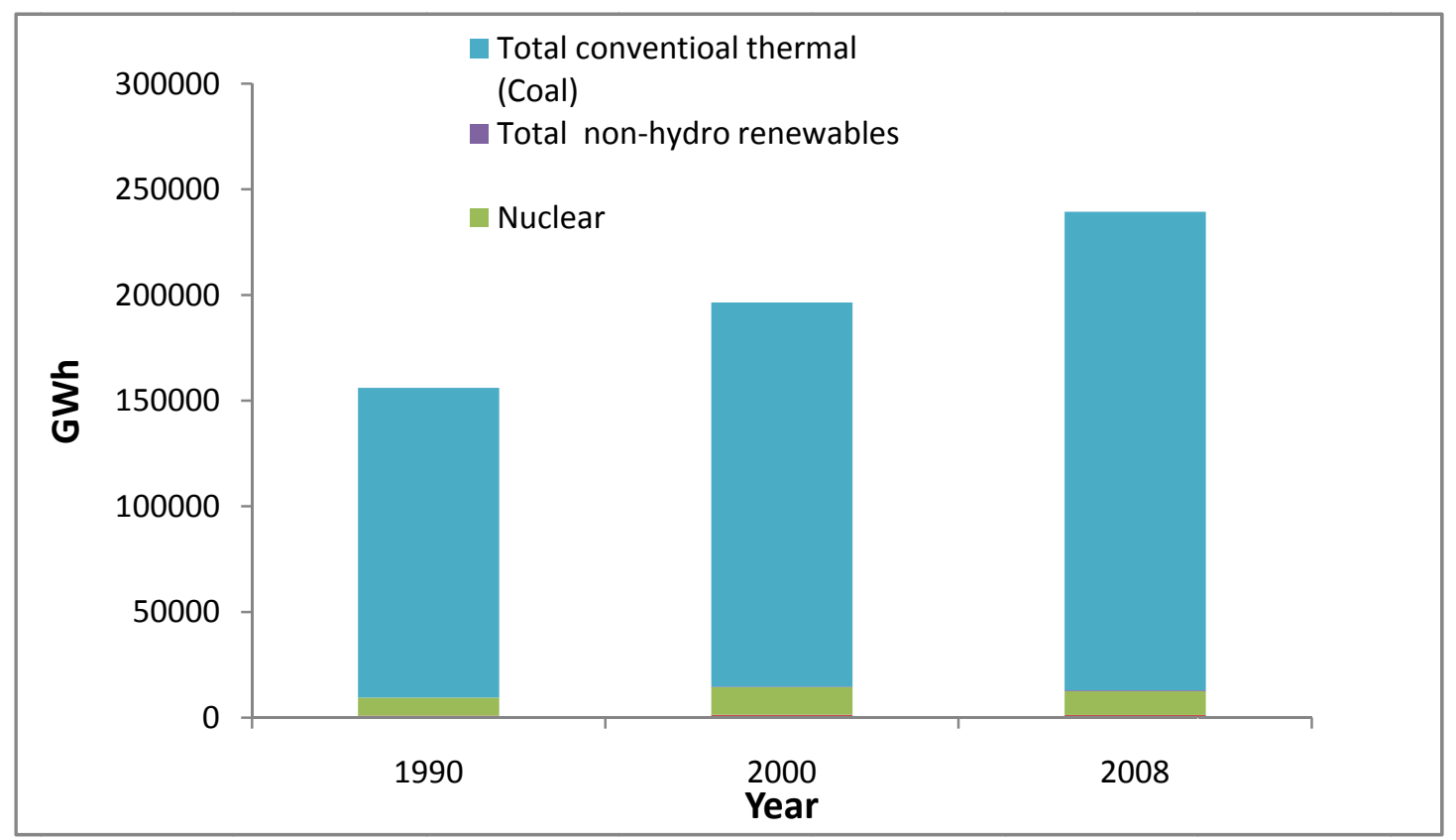

Figure 2. Electricity generation by fuel type in South Africa

(Source: Energy Information Administration, 2010) 


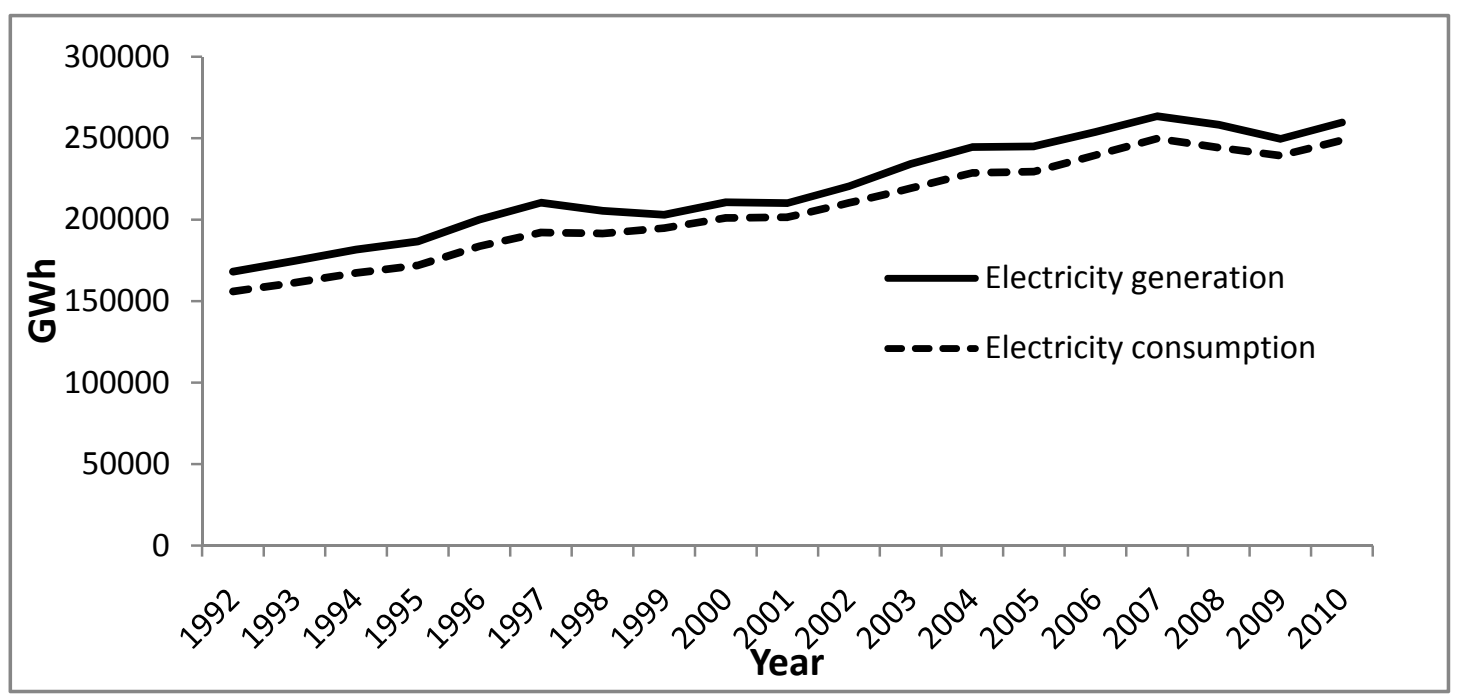

Figure 3. Annual Electricity generation and consumption (Source: STATS SA, 2011)

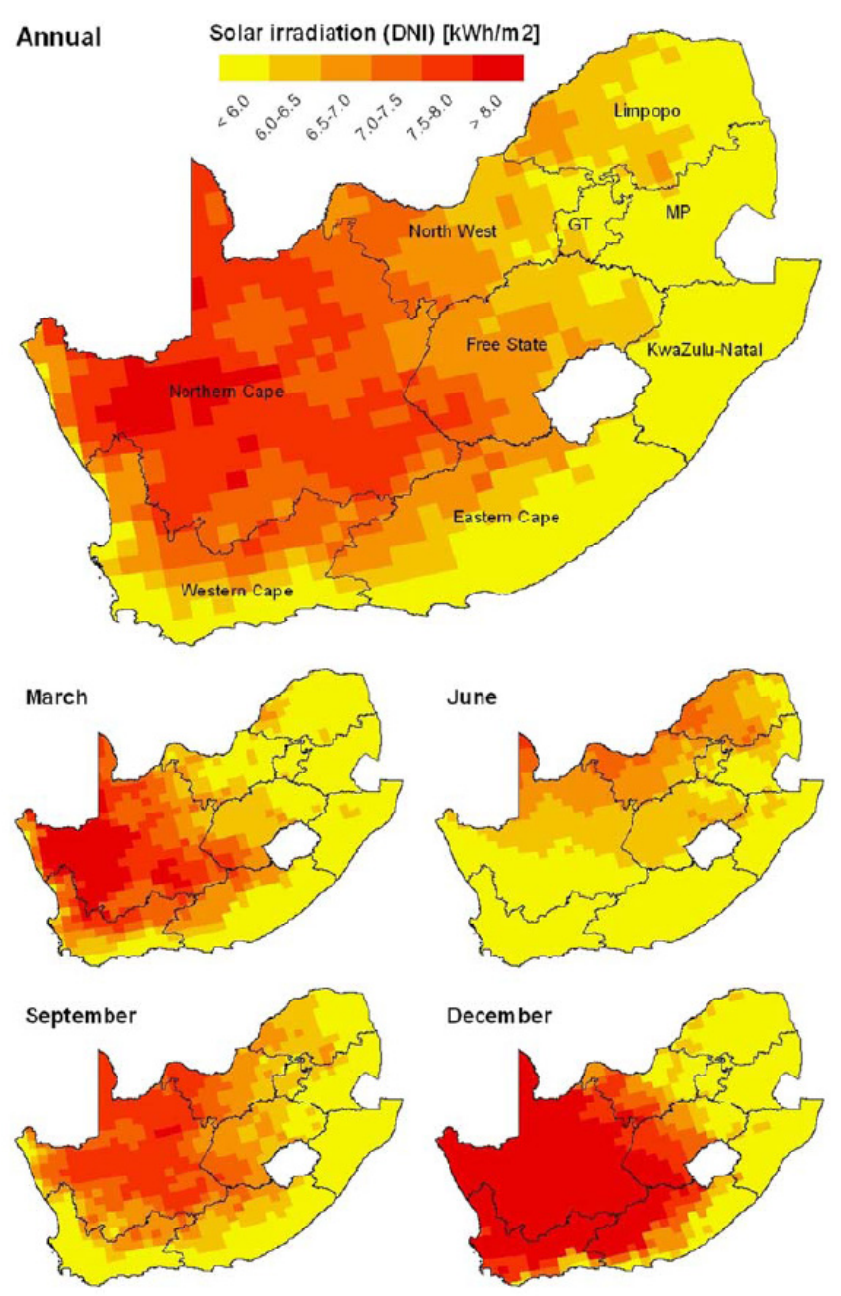

Figure 4. Maps showing the average daily direct normal irradiation in South Africa for the whole year and for months of March, June, September and December (Source: Fluri, 2009) 